CLINICAL STUDY

\title{
SAGE analysis highlights the putative role of underexpression of ribosomal proteins in GH-secreting pituitary adenomas
}

\author{
Deison Soares de Lima ${ }^{1}$, Clarissa Silva Martins ${ }^{1}$, Beatriz Maria de Carvalho Paixao ${ }^{1}$, Fernando Colbari Amaral ${ }^{1}$, \\ Leandro Machado Colli ${ }^{1}$, Fabiano P Saggioro ${ }^{2}$, Luciano Neder ${ }^{2}$, Helio Rubens Machado ${ }^{3}$, \\ Anemari Ramos Dinarte dos Santos ${ }^{4}$, Daniel G Pinheiro ${ }^{4}$, Ayrton Custodio Moreira ${ }^{1}$, Wilson Araújo Silva Jr ${ }^{4}$ \\ and Margaret Castro ${ }^{1}$ \\ Departments of ${ }^{1}$ Internal Medicine, ${ }^{2}$ Pathology, ${ }^{3}$ Anatomy and Surgery and ${ }^{4}$ Genetics, School of Medicine of Ribeirao Preto, University of Sao Paulo, \\ Avenida Bandeirantes 3900, 14049-900 Ribeirao Preto, Sao Paulo, Brazil \\ (Correspondence should be addressed to M Castro; Email: castrom@fmrp.usp.br)
}

\begin{abstract}
Background: Although the molecular pathogenesis of pituitary adenomas has been assessed by several different techniques, it still remains partially unclear. Ribosomal proteins (RPs) have been recently related to human tumorigenesis, but they have not yet been evaluated in pituitary tumorigenesis. Objective: The aim of this study was to introduce serial analysis of gene expression (SAGE), a highthroughput method, in pituitary research in order to compare differential gene expression.

Methods: Two SAGE cDNA libraries were constructed, one using a pool of mRNA obtained from five GH-secreting pituitary tumors and another from three normal pituitaries. Genes differentially expressed between the libraries were further validated by real-time PCR in 22 GH-secreting pituitary tumors and in 15 normal pituitaries.

Results: Computer-generated genomic analysis tools identified 13722 and 14993 exclusive genes in normal and adenoma libraries respectively. Both shared 6497 genes, 2188 were underexpressed and 4309 overexpressed in tumoral library. In adenoma library, 33 genes encoding RPs were underexpressed. Among these, RPSA, RPS3, RPS14, and RPS29 were validated by real-time PCR. Conclusion: We report the first SAGE library from normal pituitary tissue and GH-secreting pituitary tumor, which provide quantitative assessment of cellular transcriptome. We also validated some downregulated genes encoding RPs. Altogether, the present data suggest that the underexpression of the studied RP genes possibly collaborates directly or indirectly with other genes to modify cell cycle arrest, DNA repair, and apoptosis, leading to an environment that might have a putative role in the tumorigenesis, introducing new perspectives for further studies on molecular genesis of somatotrophinomas.
\end{abstract}

European Journal of Endocrinology 167 759-768

\section{Introduction}

The molecular pathogenesis of GH-secreting pituitary adenoma initiation and progression remains partially unexplained. The involvement of different cyclin D1 alleles, p16 amplification, and methylation are still obscure. Classic proto-oncogenes, such as NRAS, MYCL1, MYCN, HRAS (HRAS1), BCL1 (CCND1), FGF4, Sea, KRAS2 (KRAS), C-erbB-2, and FOS, and tumor suppressors such as retinoblastoma gene $(R B 1)$ and P53 do not appear to have a significant role in pituitary adenoma pathogenesis $(1,2)$. Activating mutations, promoter insertions, deletions, or point mutations of PTTG (PTTG1) as well as clear correlation between PTTG expression and mitotic index in human pituitary tumors have not been described. It remains unclear whether overexpression of normal PTTG has an active role in human pituitary tumorigenesis (3).

Four genetic syndromes have provided insights into the molecular basis of pituitary tumorigenesis. Multiple endocrine neoplasia type 1 (MEN1), caused by germline mutations in MEN1 (menin) or rarely in CDKN1B (cyclin-dependent kinase (CDK) inhibitor) genes, is an autosomal dominant condition associated with pituitary adenomas in $40-60 \%$ of patients (4). In Carney complex (CNC), unlike MEN1, only GH-secreting adenomas have been described. In this condition, the normal allele of the regulatory subunit type 1 of the cAMP-dependent protein kinase A gene (PRKAR1A) is mutated or lost (5). Pituitary adenomas of all types can occur in a familial setting in the absence of MEN1 and $\mathrm{CNC}$ - this phenotype is termed familial isolated 
pituitary adenomas (6). Germline inactivating mutations in the AIP gene, which maps at $11 \mathrm{q} 13$ and encodes the aryl hydrocarbon receptor interacting protein, have been found in some of these families (7). McCune-Albright syndrome, which has been associated with GH-secreting pituitary adenomas, results from somatic mutations in the adenylate cyclase-stimulating $\mathrm{G}$ alpha protein gene (GNAS1 (GNAS)) (8). In addition, in $\sim 40 \%$ of isolated somatotroph adenomas, activating mutations of the GNAS1 were identified and remain the most important pathogenic mechanism yet defined for human pituitary adenomas (9).

New concepts in biology point out that microRNAs (10) and ribosomal proteins (RPs) $(11,12)$ can act as gene expression regulators, controlling multiple biological processes, including cancer. RPs are core proteins that come together with rRNA in the nucleolus to form the small and the large subunits (40S and 60S) of the ribosome (11). Several eukaryotic RPs have also been linked to extra-ribosomal functions, including DNA replication, transcription, splicing, cell growth, proliferation, apoptosis, and DNA repair. Recently, RP gene mutations or altered expression were found in many human tumors such as breast, prostate, uterine cervix, esophagus, and liver carcinoma as well as glioblastoma (11).

Serial analysis of gene expression (SAGE) is a powerful high-throughput genomic approach, which is based on generating, cloning, and sequencing concatenated short sequence tags, each representing a single transcript derived from target tissue mRNA (13). It has a significant advantage over microarray-based analysis as it allows detection of the expression of thousands of genes in a quantitative manner without previous knowledge of their coding sequences. It has been applied to identify a number of genes that are over- or underexpressed in the transcriptome of different types of cancer (14).

This study reports the first SAGE library from normal pituitary tissue and GH-secreting pituitary tumors. We also described and validated differentially expressed RP genes in both tissues, which could be involved in the pathogenesis of somatotrophinomas.

\section{Materials and methods}

\section{Subjects}

This study was approved by the Ethics Committee of Hospital of School of Medicine of Ribeirao Preto, University of Sao Paulo, and according to the Declaration of Helsinki requirements, and written informed consent was obtained from all participants.

Twenty-two patients (13 females, nine males; mean age, $42 \pm 10.5$ years) were diagnosed as having acromegaly based on the failure of the $\mathrm{GH}$ suppression of $<1 \mu \mathrm{g} / \mathrm{l}$ after an oral glucose tolerance test (oGTT) and a high insulin-like growth factor 1 (IGF1) level, presented as the upper limit of normal range for sexand age-matched controls (15) (Table 1). Plasma GH was determined by a solid-phase immunofluorometric assay in duplicate, calibrated against the WHO 2nd International Standard 98/574 Reference Preparation for $22 \mathrm{kDa}$ rhGH (somatropin; $1 \mu \mathrm{g} / \mathrm{l}$ corresponding to $3 \mathrm{mU} / \mathrm{l}$ ) acquired from the National Institute for Biological Standards and Control (NIBSC; Hertfordshire, $\mathrm{UK})$. The limit of detection for $\mathrm{GH}$ was $0.095 \mu \mathrm{g} / \mathrm{l}$ and the intra- and interassay coefficients of variation (CV) were 5.5 and $11.7 \%$ respectively. IGF1 was determined in duplicate by immunoradiometric assay after acid extraction (Diagnostic System Laboratories, Inc., Webster, TX, USA). The limit of detection for IGF1 was $10 \mu \mathrm{g} / \mathrm{l}$, and the intra- and interassay CV were 5 and $11.3 \%$ respectively $(15)$. All patients underwent visual field evaluation and magnetic resonance imaging.

GH-secreting pituitary tumor samples were obtained during transsphenoidal surgery; part of the sample was processed for routine histopathological and immunohistochemical studies, and part was snap-frozen and stored at $-70{ }^{\circ} \mathrm{C}$ for molecular biology studies. All samples were microdissected by an experienced pathologist in order to separate any nontumoral tissue and disrupted using a Polytron homogenizer. Fifteen normal pituitaries were obtained during autopsies from subjects who had natural death without previous evidence of any endocrine disease or neurological abnormality.

\section{RNA and DNA extraction}

Total RNA and DNA were isolated from frozen tissues using TRIzol reagent (Invitrogen Life Technologies, Inc.). The quality of the RNA and DNA was evaluated by spectrophotometry and agarose gel electrophoresis.

\section{GNAS and AIP mutation screening}

Codons 201 and 227 of the GNAS gene and the entire AIP gene were directly sequenced. Primers and PCR conditions to detect activating mutations of GNAS gene (gsp oncogene) and AIP mutations in tumoral DNA were previously described $(7,16)$.

\section{SAGE library construction}

Two SAGE cDNA libraries were constructed, one using a pool of mRNA obtained from five GH-secreting pituitary tumors and another from a pool of mRNA obtained from three normal pituitaries. A total of $23 \mu \mathrm{g}$ of purified RNA from a pool of tumoral or normal samples were used for the construction of each library using I-SAGE kit (Invitrogen Life Technologies, Inc.). Binding mRNA to oligo (dT) magnetic beads, cDNA synthesis and all subsequent steps of the SAGE procedure were essentially performed as described previously (13). After synthesis, cDNA was digested with NlaIII as anchoring enzyme. 
Table 1 Clinical, biochemical, imaging findings, and follow-up of patients with acromegaly.

\begin{tabular}{|c|c|c|c|c|c|c|c|c|c|c|}
\hline Patient & Gender & $\begin{array}{c}\text { Age } \\
\text { (years) }\end{array}$ & $\begin{array}{c}\text { Tumor } \\
\text { diameter } \\
(\mathrm{MRI} ; \mathrm{cm})\end{array}$ & IHC & $\begin{array}{l}\text { IGF1 } \\
\text { (\% ULNR) }\end{array}$ & $\begin{array}{l}\text { GNAS } \\
\text { mutation }\end{array}$ & $\begin{array}{l}\text { GH } \\
\text { (oGTT; } \\
\text { ng/ml) }\end{array}$ & $\begin{array}{l}\text { Remission } \\
\text { after } \\
\text { surgery }\end{array}$ & $\begin{array}{l}\text { SRL } \\
\text { therapy }\end{array}$ & $\begin{array}{l}\text { Disease } \\
\text { control }\end{array}$ \\
\hline 1 & $\mathrm{~F}$ & 28 & 2.4 & $\mathrm{GH}, \mathrm{PRL}, \mathrm{FSH}, \mathrm{LH}$ & 480 & p.Q227L & 10.4 & No & Yes & Yes \\
\hline 2 & $M$ & 29 & 3.0 & $\mathrm{GH}, \mathrm{PRL}$ & 210 & No & 52.0 & No & Yes & No \\
\hline 3 & $\mathrm{~F}$ & 43 & 1.0 & $\mathrm{GH}, \mathrm{PRL}, \mathrm{LH}$ & 205 & No & 17.0 & Yes & No & Yes \\
\hline 4 & $M$ & 42 & 1.5 & GH, PRL, LH, FSH, TSH & 921 & No & 22.3 & Yes & No & Yes \\
\hline 5 & $\mathrm{~F}$ & 55 & 0.8 & $\mathrm{GH}, \mathrm{PRL}$ & 680 & p.R201C & 1.7 & Yes & Yes & Yes \\
\hline 6 & $\mathrm{M}$ & 34 & 1.3 & $\mathrm{GH}, \mathrm{PRL}$ & 119 & p.R201C & 5.4 & No & Yes & Yes \\
\hline 7 & $\mathrm{~F}$ & 50 & 1.2 & $\mathrm{GH}$ & NA & No & 22.0 & Yes & No & Yes \\
\hline 8 & $\mathrm{~F}$ & 53 & 1.1 & GH & 232 & p.R201H & 3.4 & No & Yes & Yes \\
\hline 9 & $\mathrm{~F}$ & 30 & 1.9 & $\mathrm{GH}$ & 410 & p.R201C & 7.1 & No & Yes & Yes \\
\hline 10 & $\mathrm{~F}$ & 37 & 3.0 & $\mathrm{GH}, \mathrm{PRL}$ & 297 & No & 67.0 & No & Yes & Yes \\
\hline 11 & $M$ & 36 & 1.6 & $\mathrm{GH}$ & 404 & No & 32.4 & No & Yes & No \\
\hline 12 & $\mathrm{~F}$ & 50 & 1.1 & $\mathrm{GH}, \mathrm{PRL}$ & 246 & p.R201C & NA & No & Yes & $N A^{b}$ \\
\hline 13 & $M$ & 57 & 2.0 & GH, PRL & 758 & No & 28.9 & No & Yes & No \\
\hline 14 & $M$ & 39 & 2.7 & $\mathrm{GH}, \mathrm{PRL}$ & 360 & $\mathrm{No}^{\mathrm{a}}$ & 17.0 & No & Yes & $\mathrm{No}^{\mathrm{b}}$ \\
\hline 15 & $\mathrm{~F}$ & 52 & 3.4 & $\mathrm{GH}, \mathrm{PRL}, \mathrm{LH}$ & 376 & No & 19.5 & No & Yes & Yes \\
\hline 16 & $M$ & 33 & 2.0 & GH, TSH, PRL, LH & 485 & p.R201C & 8.5 & No & Yes & No \\
\hline 17 & $\mathrm{~F}$ & 44 & 2.0 & $\mathrm{GH}, \mathrm{PRL}$ & 835 & No & 1.6 & No & Yes & No \\
\hline 18 & $\mathrm{~F}$ & 57 & 1.8 & $\mathrm{GH}$ & 492 & NA & 1.3 & No & Yes & Yes \\
\hline 19 & $\mathrm{~F}$ & 54 & 2.8 & $\mathrm{GH}$ & 542 & No & 19.2 & No & Yes & No \\
\hline 20 & $M$ & 42 & 2.0 & $\mathrm{GH}$ & NA & p.Q227L & 104.0 & Yes & No & Yes $^{b}$ \\
\hline 21 & $\mathrm{~F}$ & 31 & 2.1 & $\mathrm{GH}, \mathrm{PRL}, \mathrm{TSH}$ & 337 & No & 117.0 & No & Yes & No \\
\hline 22 & $M$ & 26 & 5.8 & $\mathrm{GH}, \mathrm{TSH}, \mathrm{FSH}, \mathrm{PRL}$ & NA & p.R201H & 338.0 & No & $\mathrm{No}^{\mathrm{b}}$ & $N A^{b}$ \\
\hline
\end{tabular}

F, female; M, male; IGF1, insulin-like growth factor 1; ULNR, upper limit of normal range; MRI, magnetic resonance imaging; IHC, immunohistochemistry; $\mathrm{PRL}$, prolactin; SRL, somatostatin receptor ligand; NA, not available.

apatient presenting AIP p.R304X mutation.

${ }^{b}$ Patients without long-term follow-up.

The 3'-terminal cDNA fragments were captured using magnetic stand. SAGE cDNA tags $(\sim 10 \mathrm{bp}$ attached to the linker) were generated by binding of linkers to the NlaIII-compatible sticky ends and then were digested by BsmFI (site present in linkers). After blunting of the linker-cDNA products, dimerization, and PCR amplification (30 cycles) were performed using primers directed against linker sequences, which were excised by BsmFI digestion. The released ditag was purified from the excised linkers by PAGE and bound to long multimers of ditags (concatemers) separated by NlaIII sites. Size separation by PAGE was performed and a 300-500 bp fraction was excised from gel, purified, and cloned into the SphI site of pZero-1 (Invitrogen Life Technologies, Inc.). The resulting colonies were gridded in 96-well microtiter dishes containing Low Salt LB+ Zeocin $(100 \mu \mathrm{g} / \mathrm{ml})$, grown overnight at $37^{\circ} \mathrm{C}$, and stored at $4{ }^{\circ} \mathrm{C}$ until further use. Sequencing was performed using the DYEnamic ET Dye Terminator Kit (GE Healthcare, Piscataway, NJ, USA) and a MegaBACE DNA Analysis System (GE Healthcare).

The sequences were further analyzed using SAGE2000 Software (Invitrogen, Carlsbad, CA, USA) and, briefly, the analysis steps were as follows: locate the NlaIII sites (i.e. CATG 'punctuation signals') within the ditag concatemer; extract ditags of 20-26 bases, length, which are located between the sites; remove repeat occurrences of ditags, including repeat occurrences in the reversecomplemented orientation; define tags as the end-most ten bases of each ditag, reverse-complementing the right-handed tag; remove tags corresponding to linker (i.e. TCCCCGTACA and TCCCTATTAA), as well as those with unspecified bases (i.e. bases other than A, C, G, or T); and for each tag, count its number of occurrences. The product of this processing is a list of tags with their corresponding count values and thus is a digital representation of cellular gene expression (17).

Tag frequency tables were constructed from data by the SAGE analysis software, with the minimum tag count set at 1 and the maximum ditag length set at $28 \mathrm{bp}$, and the parameters were set as default. The annotation was based on the SAGEmap Database (http://www.ncbi.nlm.nih.gov/SAGE). Statistical analysis was carried out with the H2G Software (http://gdm.fmrp.usp.br) for the comparison of two SAGE libraries, using as reference the normal pituitary library to evaluate over- and underexpressed genes.

\section{RT-PCR and real-time PCR quantification}

Genes differentially expressed between the libraries were further validated by real-time PCR in $22 \mathrm{GH}$-secreting pituitary tumors and in 15 normal pituitaries, including those previously used in library construction. Approximately $1 \mu \mathrm{g}$ total RNA was used in a RT reaction of $10 \mu \mathrm{l}$ using $2.5 \mathrm{M}$ oligo (dT), $5.5 \mathrm{mM} \mathrm{MgCl}_{2}, 2.0 \mathrm{mM}$ dNTP, $20 \mathrm{U} / \mathrm{l}$ RNAse inhibitor, $50 \mathrm{U} / \mathrm{l}$ MultiScribe TaqMan, and $10 \times$ RT buffer in a first-strand cDNA synthesis kit (TaqMan RT reagents; Applied Biosystems, Branchburg, NJ, USA). The RT-PCR cycle sequence was 
$25^{\circ} \mathrm{C}$ for $10 \mathrm{~min}, 48^{\circ} \mathrm{C}$ for $30 \mathrm{~min}$, and $95^{\circ} \mathrm{C}$ for $5 \mathrm{~min}$. Control reactions were performed to exclude genomic DNA contamination.

RPSA, RPS3, RPS7, RPS14, and RPS29 genes were identified among the differently expressed genes between somatotroph adenoma and normal pituitary libraries. cDNA of each RP gene and of GUSB, TBP, and PGK1, used as housekeeping genes, was separately amplified in duplicates, in a total volume of $12 \mu \mathrm{l}$, in real-time PCR assays, using Applied Biosystems 7500 Real-Time PCR System (Foster City, CA, USA). In addition, by real-time PCR, we also evaluate SSTR2 gene expression in all samples. We used Applied Biosystems-customized assay by-design for RPS 3 (TaqMan Gene Expression Assay 79710183), RPS7 (TaqMan Gene Expression Assay 79686327), RPS14 (TaqMan Gene Expression Assay 79685288), RPS29 (TaqMan Gene Expression Assay 79685936), assay on demand for RPSA (TaqMan Gene Expression Assay Hs01080364_m1), and inventoried assay for SSTR2 (TaqMan Gene Expression Assay Hs00990356_m1). For endogenous controls, we used PGK1 (TaqMan Gene Expression Assay Hs99999906_m1), TBP (TaqMan Gene Expression Assay Hs99999910_m1), and GUSB (TaqMan Gene Expression Assay Hs99999908_m1).

Reactions were incubated in a 96 -well optical plate at $95^{\circ} \mathrm{C}$ for $10 \mathrm{~min}$, followed by 40 cycles of $95^{\circ} \mathrm{C}$ for $15 \mathrm{~s}$, and $60^{\circ} \mathrm{C}$ for $1 \mathrm{~min}$. The cycle threshold $(\mathrm{Ct})$ was defined as the fractional cycle number at which the fluorescence surpasses the fixed threshold. The Ct data were performed using default threshold settings.

Data were presented as the $\mathrm{Ct}$ of each sample of each target gene normalized by the endogenous controls (GUSB, TBP, and PGK1), Ct-median expression, and calibrated by $\Delta C$ t-median value obtained from all normal pituitary tissues. Each gene expression in normal pituitary and tumoral tissue samples are presented as mean, s.D., median, and range. Relative quantification of gene expression was calculated using the $2^{-\Delta \Delta C t}$ method (18). Fold change of gene expression observed in somatotroph adenomas compared with normal pituitaries was determined by the median of $2^{-\Delta \Delta C t}$ values of the former, related to median of $2^{-\Delta \Delta C t}$ values of the latter.

\section{Statistical analysis}

Statistical analyses were carried out using MannWhitney $U$ test for continuous variables. Fisher's exact test was used for categorical data such as the presence of GNAS mutation, tumor size, remission after transsphenoidal surgery, control after somatostatin receptor ligand (SRL) therapy, and the presence of exclusive GH staining on immunohistochemistry (IHC). Data were analyzed by GraphPad Prism 4 Software (San Diego, CA, USA) and differences were considered significant at $P<0.05$. For analysis of correlation between gene expression of RP genes and SSTR2, the Pearson's correlation coefficient was used.

\section{Results \\ Subjects}

Table 1 shows the clinical, biochemical, and imaging findings, and follow-up of patients with GH-secreting pituitary tumors. Magnetic resonance imaging diagnosed macroadenoma in 21 out of 22 patients. Exclusive $\mathrm{GH}$ staining on IHC was observed in seven patients $(31.8 \%), \mathrm{GH}$ and prolactin (PRL) staining in eight patients (36.4\%), and GH, PRL, and glycoprotein hormones (LH, FSH, and TSH) in seven patients (31.8\%).

Disease control was defined by GH level suppressed by $<1 \mathrm{ng} / \mathrm{ml}$ after oGTT and normal IGF1 levels for sexand age-matched controls. Seventeen patients $(77.2 \%)$ had no clinical or biochemical remission after transsphenoidal surgery and were submitted to complementary therapy with SRL. Among these patients, seven $(41.1 \%)$ achieved control. Patient 19 achieved disease control after SRL associated with dopamine agonist, while patients $2,11,13$, and 16 underwent second surgery, radiotherapy, and treatment with dopamine agonist.

Among 22 patients, DNA of one patient was not available for GNAS and AIP mutation screening. Somatic activating GNAS mutations (p.R201C, p.R201H, and p.Q227L) were found in nine out of 21 patients $(42.8 \%)$. Only one patient harbored somatic AIP p.R304X mutation (4.7\%) and it was not associated with GNAS mutation.

\section{SAGE analysis and selection of genes to validation by real-time PCR}

Data of SAGE libraries constructed from samples of normal pituitary and $\mathrm{GH}$-secreting pituitary tumor were included in the Genome Data Mining Website for normal pituitary cDNA library, http://gdm.fmrp.usp. $\mathrm{br} / \mathrm{h} 2 \mathrm{~g} /$ library/695 and for GH pituitary tumor cDNA library, http://gdm.fmrp.usp.br/h2g/library/1145 of the Molecular Genetics and Bioinformatics Laboratory of the Department of Genetics of School of Medicine of Ribeirao Preto, University of Sao Paulo. The libraries analysis were performed using a web-based tool S3T (Score System for Sequence Tags) available for free at http://gdm.fmrp.usp.br/s3t/ (19). The analysis of normal and adenoma libraries identified 21030 and 22329 unique SAGE tags respectively. Computergenerated genomic analysis tools (http://gdm.fmrp. usp.br) identified 13722 exclusive genes in normal pituitary and 14993 in somatotroph adenoma cDNA library. Both libraries shared 6497 genes, 2188 underexpressed and 4309 overexpressed in tumoral library. Of interest, PTTG gene was not expressed in tumor library generated by the present SAGE. Differential expression of genes related to cell adhesion, cell differentiation, cell cycle, and apoptosis were also demonstrated between 
normal pituitary tissue and GH-secreting pituitary tumors (Table 2).

In the normal library, SAGE also showed overexpression of POMC (62-fold), LH $\beta$ subunit (54-fold), TSH (24-fold), PRL (fivefold), and exclusive FSH $\beta$ subunit expression compared with tumoral library. On the other hand, GH-secreting adenoma library showed higher expression of GH2 gene (3.2-fold).

In addition, SAGE data revealed 33 under- and 14 overexpressed RP tags in tumors. Among the underexpressed RP genes, five of them - RPSA, RPS3, RPS7, RPS14, and RPS29 - were selected for validation by real-time PCR based on Ingenuity Pathway Analysis (Ingenuity Systems, www.ingenuity.com). We observed underexpression of RPSA ( -1.4 -fold; $P=0.004), R P S 3$ ( -1.8 -fold; $P=0.03)$, RPS14 $(-1.8$-fold; $P=0.001)$, and RPS29 $(-2.9$-fold; $P=0.002)$. RPS7 expression showed only a tendency to underexpression $(-1.2$-fold; $P=0.08)$ in $\mathrm{GH}$-secreting pituitary tumor compared with normal pituitaries samples (Table 3).

We also observed no difference between SSTR2 expression by real-time PCR in GH-secreting pituitary tumors and normal pituitaries $(P=0.4)$. However, SSTR 2 overexpression in tumoral samples was associated with disease control after treatment with SRL $(P=0.01)$.

There was no relationship between RPSA, RPS3, RPS14, and RPS29 expression and the presence of GNAS mutation, IGF1 or GH levels, tumor size, exclusive GH staining on IHC, remission after surgery, or disease control with SRL therapy. There was no correlation between RP gene expression and SSTR2 expression.

\section{Discussion}

This study reports the first SAGE library from normal pituitary tissue and GH-secreting pituitary tumor. SAGE data generated will be available at Gene Expression Omnibus website (http://www.ncbi.nlm.nih.gov/geo/) and will be accessed through GEO accession GSM 912557 (somatotrophinomas) and GSM912556 (normal pituitary). Our entire data will be available at this database, providing information on differently expressed genes in somatotroph adenomas for further research.

Until now, most available information on the pituitary tumor transcriptome was based on microarray studies $(20,21)$. SAGE has some advantages over microarrays because it allows detection of all expressed sequences in a tissue, including those not previously described (13). Similar to microarray, there is limitation in using SAGE method in order to compare the monoclonal somatotroph adenoma and the normal pituitary, which contains various cell types. The fact that normal pituitary tissue is composed of more than $50 \%$ somatotropic cells might, however, decrease this limitation. It is also important to point out that all high-throughput methods have exclusive advantages and limitations. Therefore, integrating different data sets will provide complementary knowledge on pituitary tumorigenesis.

The molecular profile of pituitary tumor exhibited several similarities and some differences compared with previously published data using microarray. Genes related to pituitary physiological hormone secretion, such as POMC, LH $\beta$ subunit, TSH, and PRLm were differently expressed in normal tissue library. On the other hand, GH-secreting pituitary adenoma library showed higher expression of GH2 gene (3.2-fold). Morris et al. (21), using microarray, also found that $\mathrm{GH} 2$ as well as GH-releasing hormone receptor $(G H R H R)$ genes were overexpressed in GH pituitary tumor tissue. Interestingly, PTTG gene was not expressed in tumor library generated by the present SAGE and, in the microarray study (21), its expression was similar in normal pituitary and GH-secreting tumors. These data diverge from those previously reported by comparative RT-PCR, which demonstrated ubiquitous and prevalent expression of PTTG in pituitary tumors, mainly in invasive hormone-secreting tumors (3).

In this study, differential expression of genes related to cell adhesion, cell differentiation, cell cycle, and apoptosis were also demonstrated between normal pituitary tissue and $\mathrm{GH}$-secreting pituitary tumors by SAGE. These findings have not yet been validated. However, they introduce new perspectives for further studies on molecular genesis of somatotrophinomas. Additional experiments and functional studies are required to confirm these data and the involvement of these signaling pathways in GH-secreting pituitary tumors.

SAGE also identified 33 under- and 14 overexpressed RP genes in the adenoma library, which might be involved in the poorly understood pathogenesis of GH-secreting pituitary tumors, as many extra-ribosomal functions in other cellular processes have been suggested. Indeed, RP gene mutations or altered expression have been found in many human tumors $(22,23)$. In this study, based on Ingenuity Pathway Analysis (Ingenuity Systems, www.ingenuity.com), we chose for validation five of them - RPSA, RPS3, RPS7, RPS14, and RPS29 - all involved in cell cycle regulation, apoptosis, and DNA repair. We validated, by real-time PCR, four of the five RP genes studied. Although the role of RPs in pituitary tumorigenesis has never been proposed, research at seed site analysis (http://www.ncbi.nlm.nih.gov/geo/) enables us to find a differential expression profile of all these RPs in four pituitary adenoma subtypes (GH, PRL, ACTH-secreting pituitary adenomas, and nonfunctioning pituitary adenoma), reinforcing the putative role of RPs in pituitary tumor pathogenesis (21).

$\mathrm{RP}$ genes have been identified in human diseases, especially in genetic disorders (24). Recently, 
Table 2 Under- and overexpressed genes in GH-secreting pituitary adenoma library compared with normal pituitary library, obtained by SAGE and involved in functional pathways. Under- and overexpressed genes described in this table refer to fold change inferior to -2.5 and superior to 2.5 respectively.

\begin{tabular}{|c|c|c|c|c|}
\hline SAGE tag & Unigene & $\begin{array}{l}\text { Gene } \\
\text { symbol }\end{array}$ & Gene description & $\begin{array}{l}\text { Fold } \\
\text { change }\end{array}$ \\
\hline \multicolumn{5}{|l|}{ Apoptotic pathways } \\
\hline GCAGGGTGGG & Hs.631535 & AKT2 & V-akt murine thymoma viral oncogene homolog 2 & -5.02 \\
\hline TCACTGTGGG & Hs.372331 & SPTAN1 & Spectrin, alpha, non-erythrocytic 1 (alpha-fodrin) & -4.02 \\
\hline AAGCATTAAA & Hs.520851 & PRKAR1B & Protein kinase, cAMP-dependent, regulatory, type I, beta & -3.52 \\
\hline AAAATAAAGA & Hs.73722 & $A P E X 1$ & APEX nuclease (multifunctional DNA repair enzyme) 1 & -3.52 \\
\hline CCTGCCCCCC & Hs.861 & MAPK3 & Mitogen-activated protein kinase 3 & -3.01 \\
\hline AAAAAGCAGA & Hs.443914 & SOD1 & Superoxide dismutase 1 , soluble (amyotropic lateral sclerosis 1 ) & -2.34 \\
\hline AAGCCTTGCT & Hs.444356 & GRB2 & Growth factor receptor-bound protein 2 & 2.99 \\
\hline CTGCTGCACT & Hs.271510 & GSR & Glutathione reductase & 3.98 \\
\hline CCAGTGCACT & Hs.220950 & $\mathrm{FOXO3}$ & Forkhead box $\mathrm{O} 3$ & 3.98 \\
\hline TGAATCTGGG & Hs. 436687 & SET & SET translocation (myeloid leukemia associated) & 4.98 \\
\hline \multicolumn{5}{|c|}{ Cell differentiation pathways } \\
\hline CCTAAGGCTA & Hs. 108371 & E2F4 & E2F transcription factor $4, \mathrm{p} 107 / \mathrm{p} 130$ binding & -3.01 \\
\hline TATGACTTAA & Hs. 413812 & $R A C 1$ & Ras-related $\mathrm{C} 3$ botulinum toxin substrate 1 & -2.58 \\
\hline CTCTGAGGTA & Hs. 435714 & PAK1 & P21/Cdc42/Rac1-activated kinase 1 (STE20 homolog, yeast) & -2.51 \\
\hline TGGCTGGCCA & Hs.654394 & CSF1R & $\begin{array}{l}\text { Colony stimulating factor } 1 \text { receptor, }(v \text {-fms) oncogene } \\
\text { homolog }\end{array}$ & 2.99 \\
\hline \multicolumn{5}{|c|}{ Cell adhesion pathways } \\
\hline AAAGGGTCAC & Hs.21422 & $N R C A M$ & Neuronal cell adhesion molecule & -8.04 \\
\hline TGTGGCGTAT & Hs. 556600 & MYLK & Myosin light chain kinase & -4.02 \\
\hline TTGCTGACTT & Hs.474053 & COL6A1 & Collagen, type VI, alpha 1 & -3.52 \\
\hline TGGCCTAATA & Hs. 1501 & SDC2 & Syndecan 2 & -3.45 \\
\hline TGTTTATATT & Hs.49774 & PTPRM & Protein tyrosine phosphatase, receptor type, M & -3.01 \\
\hline TGAAAACTAC & Hs.347270 & $H L A-D P A 1$ & Major histocompatibility complex, class II, DP alpha 1 & -3.01 \\
\hline GCATTGCTCA & Hs.365689 & CADM3 & Cell adhesion molecule 3 & -3.01 \\
\hline TCTTCGTCCT & Hs.493919 & MPZL1 & Myelin protein zero-like 1 & -3.01 \\
\hline TAATATTTTT & Hs. 270291 & ACTN4 & Actinin, alpha 4 & -3.01 \\
\hline GTGGAGAAAA & Hs.694732 & ITGA4 & $\begin{array}{l}\text { Integrin, alpha } 4 \text { (antigen CD49D, alpha } 4 \text { subunit of VLA-4 } \\
\text { receptor) }\end{array}$ & -3.01 \\
\hline CAGATTGCTG & Hs.705383 & $P P P 1 C B$ & Protein phosphatase 1, catalytic subunit, beta isoform & -2.51 \\
\hline GACCGCAGGA & Hs.17441 & COL4A1 & Collagen, type IV, alpha 1 & 2.99 \\
\hline CAAGAGTTTT & Hs. 503878 & NCAM1 & Neural cell adhesion molecule 1 & 2.99 \\
\hline TTTGGTTTTC & Hs.489142 & COL1A2 & Collagen, type I, alpha 2 & 2.99 \\
\hline TCAAAAAAAA & Hs.445827 & COL5A2 & Collagen, type V, alpha 2 & 3.65 \\
\hline TGGAAATGAC & Hs.172928 & COL1A1 & Collagen, type I, alpha 1 & 4.98 \\
\hline CTCCAATAAA & Hs. 471014 & TLN1 & Talin 1 & 4.98 \\
\hline GGGCGGAGCT & Hs.632717 & MYL6 & Myosin, light chain 6, alkali, smooth muscle and non-muscle & 6.97 \\
\hline ACCСTCTTCC & Hs. 181244 & $H L A-A$ & Major histocompatibility complex, class I, A & 12.94 \\
\hline \multicolumn{5}{|l|}{ Cell cycle pathways } \\
\hline CTTAATCTTG & Hs.519162 & BTG2 & BTG family, member 2 & 12.06 \\
\hline TGAGAGGGTG & Hs.74405 & $Y W H A Q$ & $\begin{array}{l}\text { Tyrosine 3-monooxygenase/tryptophan 5-monooxygenase } \\
\text { activation protein (YWHA) theta polypeptide }\end{array}$ & -6.03 \\
\hline GAATTAACAT & Hs. 513851 & YWHAE & (YWHA) epsilon polypeptide & -4.47 \\
\hline AACTCCCAGT & Hs. 110571 & $G A D D 45 B$ & Growth arrest and DNA damage inducible, beta & -4.02 \\
\hline AAAGTCTAGA & Hs.523852 & CCND1 & Cyclin D1 & -3.01 \\
\hline TAATTAAAAG & Hs.40582 & $C D C 14 B$ & $\begin{array}{l}\text { CDC14 cell division cycle } 14 \text { homolog B } \\
\text { (Saccharomyces cerevisiae) }\end{array}$ & -3.01 \\
\hline CCTAAGGCTA & Hs. 108371 & E2F4 & $\mathrm{E} 2 \mathrm{~F}$ transcription factor $4, \mathrm{p} 107 / \mathrm{p} 130$ binding & -3.01 \\
\hline TCAATCAAGA & Hs.226755 & YWHAH & (YWHA) eta polypeptide & -2.68 \\
\hline TGCATATCAT & Hs.370770 & XPO1 & Exportin 1 (CRM1 homolog, yeast) & 2.99 \\
\hline GCTGAAGGGG & Hs.483635 & FGF1 & Fibroblast growth factor 1 (acidic) & 2.99 \\
\hline CTGCACTTAC & Hs. 438720 & MCM7 & Minichromosome maintenance complex component 7 & 3.48 \\
\hline AATGTGAGTC & Hs.520974 & YWHAG & (YWHA) gamma polypeptide & 3.98 \\
\hline CGTCCCGGAG & Hs.654838 & MAD1L1 & MAD1 mitotic arrest deficient-like 1 (yeast) & 3.98 \\
\hline TCCTGCTGGC & Hs.149957 & RPS6KA1 & Ribosomal protein S6 kinase, 90 kDa, polypeptide 1 & 3.98 \\
\hline GACAAGGTTC & Hs.279562 & MYT1 & Myelin transcription factor 1 & 5.97 \\
\hline СССТССТСТС & Hs.534307 & CCND3 & Cyclin D3 & 6.97 \\
\hline
\end{tabular}


Table 3 Ribosomal protein genes in GH-secreting adenoma and normal pituitary cDNA libraries evaluated by SAGE and validated by qPCR. Frequencies $A$ and $B$ correspond to the number of each tag, obtained by SAGE, in normal and GH-secreting pituitary cDNA libraries, respectively, and normalized to 300000 total tags.

\begin{tabular}{|c|c|c|c|c|c|c|c|c|}
\hline SAGE tag & Unigene & Gene & $\begin{array}{c}\text { Frequency A } \\
\text { (normal } \\
\text { library) }\end{array}$ & $\begin{array}{c}\text { Frequency B } \\
\text { (tumor } \\
\text { library) }\end{array}$ & $\begin{array}{l}\text { Fold } \\
\text { change } \\
\text { (SAGE) }\end{array}$ & $\begin{array}{l}\text { Normal } \\
\text { pituitary } \\
\left(2^{-\Delta \Delta C t}\right)\end{array}$ & $\begin{array}{l}\text { Tumor } \\
\left(2^{-\Delta \Delta C t}\right)\end{array}$ & $\begin{array}{l}\text { Fold change } \\
\text { (qPCR) }\end{array}$ \\
\hline GAAAAATGGT & Hs.449909 & $R P S A$ & 963 & 434 & -2.2 & $\begin{array}{r}1.55 \pm 0.82 \\
0.78-3.26\end{array}$ & $\begin{array}{r}0.88 \pm 0.44 \\
0.29-2.09\end{array}$ & $-1.4(P=0.004)$ \\
\hline GAGAGTGGGG & Hs.546286 & RPS3 & 387 & 291 & -1.3 & $\begin{array}{r}1.28 \pm 0.70 \\
0.47-3.17\end{array}$ & $\begin{array}{r}0.72 \pm 0.60 \\
0.17-2.81\end{array}$ & $-1.8(P=0.03)$ \\
\hline TCGTCTTTAT & Hs.546287 & RPS7 & 99 & 19 & -5.0 & $\begin{array}{r}1.16 \pm 0.69 \\
0.26-2.93\end{array}$ & $\begin{array}{r}0.79 \pm 0.38 \\
0.25-1.64\end{array}$ & $-1.2(P=0.08)$ \\
\hline TAAACTGTTT & Hs.381126 & $R P S 14$ & 114 & 34 & -3.3 & $\begin{array}{r}1.28 \pm 0.69 \\
0.59-3.10\end{array}$ & $\begin{array}{r}0.73 \pm 0.52 \\
0.15-2.29\end{array}$ & $-1.8(P=0.001)$ \\
\hline ATAATTCTTT & Hs.156367 & RPS29 & 1474 & 528 & -2.8 & $\begin{array}{r}1.52 \pm 0.78 \\
0.41-3.30\end{array}$ & $\begin{array}{r}0.81 \pm 0.89 \\
0.09-3.78\end{array}$ & $-2.9(P=0.002)$ \\
\hline
\end{tabular}

The results for gene expression $\left(2^{-\Delta \Delta C t}\right)$ in normal pituitaries and in tumors are expressed as median \pm S.D. and range.

Ebert et al. (25) provided evidence that RPS14 is a causal gene for the $5 \mathrm{q}$-syndrome. The ribosomal gene RPS14 is required for the maturation of $40 \mathrm{~S}$ ribosomal subunits and maps to the deleted region in the $5 \mathrm{q}-$ syndrome, suggesting that this syndrome represents a disorder of aberrant ribosome biogenesis (26). However, it is conceivable that other genes (on $5 \mathrm{q}$ or elsewhere) collaborate with RPS14 to cause the disease phenotype.

RPS29, which is also underexpressed in our study, is a mediator of cell death. The overexpression of RPS 29 cDNA by transfection into thymocytes and HeLa cells induce cell shrinkage, chromatin condensation, plasma membrane alteration, nuclear fragmentation, and a distinct internucleosomal DNA ladder, typical of apoptosis (27). Downregulation of the expression of apoptosis inhibitor proteins BCL2, BCL-XL, and survivin and upregulation of pro-apoptotic p53 and Bax was also observed, suggesting a role of RPS29 in apoptosis modulation (28).

Besides RPS14 and RPS29, we also observed underexpression of RPSA and RPS 3 and a tendency of underexpression of RPS7 in somatotrophinomas compared with normal pituitaries. Mammalian cells respond to DNA damage signals by activating cell cycle checkpoints and DNA repair systems, or inducing apoptosis (29). Drosophila RPS3 has been shown to have an enzymatic activity that cleaves DNA containing 8-oxoguanine residues and an associated apurinic and apyrimidinic (AP) lyase activity that cleaves phosphodiester bonds (30). The AP endonuclease activity is inseparable from activities acting upon u.v.-irradiated DNA, which cleaves a phosphodiester bond within a cyclobutane pyrimidine dimer. Moreover, these activities are apparently associated with RPS3 (31). The ectopic expression of RPS 3 protein induces programmed cell death through the activation of caspase- 8 and caspase-3, indicating that RPS3 itself is a major determinant of cell fate (32).

Epigallocatechin-3-O-gallate (EGCG), found in green tea, has been shown to have cancer preventive activity in a variety of human organ sites (33). The inhibitory effect of EGCG on tumor cell proliferation seems to be exerted by its binding to RPSA (or $67 \mathrm{kDa}$ laminin receptor) $(34,35)$. In addition, RNAi-mediated silencing of RPSA results in abrogation of EGCG-induced apoptosis in myeloma cells by TNF $\alpha$, activated Fas, and IFN $\gamma$, which are mediated by DAPK2, a key regulatory step between the formation of deathinducing signaling complex leading to the activation of caspases (36) and p53 pathway (37). The induction of p53-like proteins (p73 and p63) provides an important alternative mechanism of cell growth arrest in the absence of p53. These proteins are not only involved in the induction of apoptosis genes but also regulate genes responsible for cell cycle arrest and DNA repair. In addition, RPSA leads to the induction of CDK inhibitors, such as p16 and p18, which can induce cell cycle arrest by preventing retinoblastoma phosphorylation (38). Finally, eukaryotic translation elongation factor 1 alpha 1 (eEF1A), which is activated by RPSA (39) and was also underexpressed in our data, is an important component of the eukaryotic translation apparatus and is indispensable for mediating anticancer activity of EGCG. Therefore, the underexpression of RPSA and eEF1A in the GH-secreting pituitary adenomas suggest that these proteins might determine the efficiency of cell proliferation and a decrease in apoptosis control, probably contributing to pituitary cancer development.

As a major negative regulator of $\mathrm{p} 53$, murine MDM2 or its human analog HDM2 oncogene plays an important role in carcinogenesis and tumor progression. By catalyzing the ubiquitination of p53, MDM2 promotes p53 protein degradation and, in turn, MDM2 binds to the transcriptional activation domain of p53 and blocks its transactivation activities (40). Several subunit proteins of the ribosome, L5, L11, L23, S3, and S7, bind to MDM2, thus stabilizing p53 and rescuing its transactivational activities $(41,42,43)$. More recently, in vitro and in vivo data suggest that 


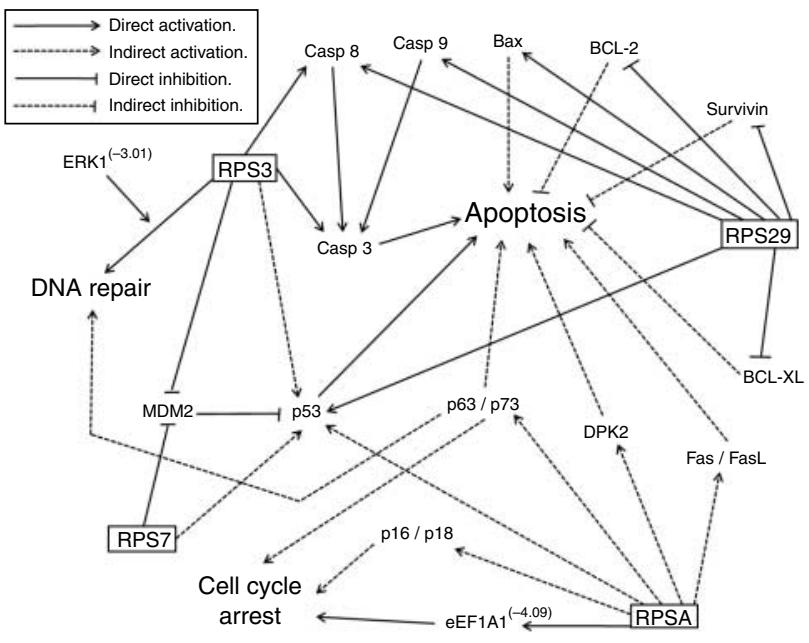

Figure 1 Summary of the possible interactions of ribosomal and other proteins involved in the control of cell cycle arrest based on Ingenuity Pathway Analysis. RPSA expression results in apoptosis initiated by activated Fas/FasL and mediated by DAPK2, leading to the activation of caspases and also by p53 pathway. It can also induce p53-like proteins (p73 and p63). The induction of cyclindependent kinase (CDK) inhibitors p16 and p18 also induce cell cycle arrest by preventing retinoblastoma phosphorylation. Eukaryotic translation elongation factor 1 alpha $1(\mathrm{eEF} 1 \mathrm{~A})$ is also an important component of the eukaryotic translation apparatus and is indispensable for cell cycle arrest. The expression of RPS3 protein induces programmed cell death through the activation of caspase-8 and caspase-3. In addition, as a major negative regulator of p53, MDM2 and its interaction with RPS3 protect p53 from MDM2 mediated ubiquitination. S7, a protein of the small subunit of the ribosome, has the capacity to stabilize p53 by binding to MDM2. Ribosomal protein S29 induces downregulation of the expression of inhibitors of apoptosis proteins BCL2, BCL-XL, and survivin and upregulation of pro-apoptotic $\mathrm{p} 53$ and Bax. Therefore, the underexpression of RPSA and eEF1A, RPS3 and S7, and S29 collaborate directly or indirectly with other genes to cause alterations on cell cycle arrest, DNA repair, and apoptosis, affecting the genomic integrity.

at least one biological end point of the interaction of RPS3 with p53 and MDM2 is to protect p53 from MDM2-mediated ubiquitination $(44,45)$. In addition, RPS7, another protein of the small subunit of the ribosome, has the capacity to stabilize $\mathrm{p} 53$ by binding to MDM2 (42). Therefore, the underexpression of RPS3 and RPS7, which act as a scaffold for the additional binding of MDM2 and p53, would affect the genomic integrity facilitating GH-secreting pituitary adenoma development. Indeed, the RPS3 is located at 11q13.3q13.5, a locus where AIP, a pituitary adenoma susceptibility gene, has been identified. Germline mutations in AIP cause a low-penetrance pituitary adenoma predisposition, with particularly high relative risk of GH-secreting pituitary adenomas. As AIP identification, a number of single-exon and partial/ whole-gene deletions detected in several tumor suppressor genes have been reported to cause hereditary tumor susceptibility (7). AIP as well as MEN1 gene are located from $61897 \mathrm{~K}$ to $64592 \mathrm{~K}$, and RPS3 is closely located at $72424 \mathrm{~K}$ on 11q.13; therefore, the underexpression of RPS 3 gene could modulate AIP and/or MEN1 genes or similar to them might act as a tumor suppressor gene.

In conclusion, we report the first SAGE libraries from normal pituitary tissue and GH-secreting pituitary tumor, which provide a quantitative assessment of the cellular transcriptome. Differential expression of genes related to cell adhesion, cell differentiation, cell cycle, and apoptosis were demonstrated by SAGE, introducing new perspectives for further studies. We validated some underexpressed genes that encode RPs. The data observed in this sample suggest that the underexpression of the studied RP genes possibly collaborates directly or indirectly with other genes, as summarized in Fig. 1, to modify cell cycle arrest, DNA repair, and apoptosis, leading to an environment that might have a putative role in the somatotrophinoma tumorigenesis.

\section{Declaration of interest}

The authors declare that there is no conflict of interest that could be perceived as prejudicing the impartiality of the research reported.

\section{Funding}

This work was supported by grants from Fundação de Amparo a Pesquisa do Estado de Sao Paulo (FAPESP), Sao Paulo, Brazil; process no. $07 / 51004-5$ and $07 / 58365-3$.

\section{Acknowledgements}

The authors want to thank the clinical support of Dr Paula Elias and the expert technical support of Adriana Marques.

\section{References}

1 Melmed S. Pathogenesis of pituitary tumors. Nature Reviews. Endocrinology 20117 257-266. (doi:10.1038/nrendo.2011.40)

2 Levy A. Molecular and trophic mechanisms of tumorigenesis. Endocrinology and Metabolism Clinics of North America 200837 23-50, vii. (doi:10.1016/j.ecl.2007.10.009)

3 Zhang X, Horwitz GA, Heaney AP, Nakashima M, Prezant TR, Bronstein MD \& Melmed S. Pituitary tumor transforming gene (PTTG) expression in pituitary adenomas. Journal of Clinical Endocrinology and Metabolism $1999 \mathbf{8 4}$ 761-767. (doi:10.1210/ jc. 84.2.761)

4 Vandeva S, Jaffrain-Rea ML, Daly AF, Tichomirowa M, Zacharieva $S$ \& Beckers A. The genetics of pituitary adenomas. Best Practice \& Research. Clinical Endocrinology \& Metabolism 2010 24 461-476. (doi:10.1016/j.beem.2010.03.001)

5 Lytras A \& Tolis G. Growth hormone-secreting tumors: genetic aspects and data from animal models. Neuroendocrinology $2006 \mathbf{8 3}$ 166-178. (doi:10.1159/000095525)

6 Beckers A \& Daly AF. The clinical, pathological, and genetic features of familial isolated pituitary adenomas. European Journal of Endocrinology 2007157 371-382. (doi:10.1530/EJE-07-0348)

7 Vierimaa O, Georgitsi M, Lehtonen R, Vahteristo P, Kokko A, Raitila A, Tuppurainen K, Ebeling TM, Salmela PI, Paschke R, et al. Pituitary adenoma predisposition caused by germline mutations in the AIP gene. Science 2006312 1228-1230. (doi:10.1126/ science.1126100) 
8 Horvath A \& Stratakis CA. Clinical and molecular genetics of acromegaly: MEN1, Carney complex, McCune-Albright syndrome, familial acromegaly and genetic defects in sporadic tumors. Reviews in Endocrine \& Metabolic Disorders 2008 9 1-11. (doi:10.1007/s11154-007-9066-9)

9 Landis CA, Masters SB, Spada A, Pace AM, Bourne HR \& Vallar L. GTPase inhibiting mutations activate the alpha chain of Gs and stimulate adenylyl cyclase in human pituitary tumours. Nature 1989340 692-696. (doi:10.1038/340692a0)

10 Meltzer PS. Cancer genomics: small RNAs with big impacts. Nature 2005435 745-746. (doi:10.1038/435745a)

11 Ruggero D \& Pandolfi PP. Does the ribosome translate cancer? Nature Reviews. Cancer 20033 179-192. (doi:10.1038/nrc1015)

12 Lindström MS. Emerging functions of ribosomal proteins in genespecific transcription and translation. Biochemical and Biophysical Research Communications 2009379 167-170. (doi:10.1016/j. bbrc.2008.12.083)

13 Velculescu VE, Zhang L, Vogelstein B \& Kinzler KW. Serial analysis of gene expression. Science 1995270 484-487. (doi:10.1126/ science.270.5235.484)

14 Kirschbaum-Slager N, Parmigiani RB, Camargo AA \& de Souza SJ. Identification of human exons overexpressed in tumors through the use of genome and expressed sequence data. Physiological Genomics 200521 423-432. (doi:10.1152/physiolgenomics. 00237.2004 )

15 Elias PCL, Lugao HB, Pereira MC, Machado HR, Castro M \& Moreira AC. Discordant nadir GH after oral glucose and IGF-I levels on treated acromegaly: refining the biochemical markers of mild disease activity. Hormone and Metabolic Research 201042 50-55. (doi:10.1055/s-0029-1239522)

16 Freda PU, Chung WK, Matsuoka N, Walsh JE, Kanibir N, Kleinman G, Wang Y, Bruce JN \& Post KD. Analysis of GNAS mutations in 60 growth hormone secreting pituitary tumors: correlation with clinical and pathological characteristics and surgical outcome based on highly sensitive GH and IGF-I criteria for remission. Pituitary 200710 275-282. (doi:10.1007/ s11102-007-0058-2)

17 Lal A, Lash AE, Altschul SF, Velculescu V, Zhang L, McLendon RE, Marra MA, Prange C, Morin PJ, Polyak K, Papadopoulos N, Vogelstein B, Kinzler KW, Strausberg RL \& Riggins GJ. A public database for gene expression in human cancers. Cancer Research $1999595403-5407$.

18 Pfaffl MW. A new mathematical model for relative quantification in real-time RT-PCR. Nucleic Acids Research 200129 e45. (doi:10.1093/nar/29.9.e45)

19 Pinheiro DG, Galante PA, de Souza SJ, Zago MA \& Silva WA. A score system for quality evaluation of RNA sequence tags: an improvement for gene expression profiling. BMC Bioinformatics 200910 170. (doi:10.1186/1471-2105-10-170)

20 Evans CO, Young AN, Brown MR, Brat DJ, Parks JS, Neish AS \& Oyesiku NM. Novel patterns of gene expression in pituitary adenomas identified by complementary deoxyribonucleic acid microarrays and quantitative reverse transcription-polymerase chain reaction. Journal of Clinical Endocrinology and Metabolism 200186 3097-3107. (doi:10.1210/jc.86.7.3097)

21 Morris DG, Musat M, Czirjak S, Hanzely Z, Lillington DM, Korbonits M \& Grossman AB. Differential gene expression in pituitary adenomas by oligonucleotide array analysis. European Journal of Endocrinology 2005153 143-151. (doi:10.1530/eje.1. 01937)

22 Bertucci F, Salas S, Eysteries S, Nasser V, Finetti P, Ginestier C, Charafe-Jauffret E, Loriod B, Bachelart L, Montfort J, et al. Gene expression profiling of colon cancer by DNA microarrays and correlation with histoclinical parameters. Oncogene 200423 1377-1391. (doi:10.1038/sj.onc.1207262)

23 Lai MD \& Xu J. Ribosomal proteins and colorectal cancer. Current Genomics 20078 43-49. (doi:10.2174/138920207780076938)

24 Draptchinskaia N, Gustavsson P, Andersson B, Pettersson M, Willig TN, Dianzani I, Ball S, Tchernia G, Klar J, Matsson H, et al.
The gene encoding ribosomal protein S19 is mutated in DiamondBlackfan anaemia. Nature Genetics 199921 169-175. (doi:10. 1038/5951)

25 Ebert BL, Pretz J, Bosco J, Chang CY, Tamayo P, Galili N, Raza A, Root DE, Attar E, Ellis SR \& Golub TR. Identification of RPS14 as a 5q-syndrome gene by RNA interference screen. Nature 2008451 335-339. (doi:10.1038/nature06494)

26 Pellagatti A, Hellstrom-Lindberg E, Giagounidis A, Perry J, Malcovati L, Della Porta MG, Jadersten M, Killick S, Fidler C, Cazzola M, Wainscoat JS \& Boultwood J. Haploinsufficiency of RPS14 in 5q-syndrome is associated with deregulation of ribosomal- and translation-related genes. British Journal of Haematology $2008 \mathbf{1 4 2}$ 57-64. (doi:10.1111/j.1365-2141. 2008.07178.x)

27 Khanna N, Reddy VG, Tuteja N \& Singh N. Differential gene expression in apoptosis: identification of ribosomal protein S29 as an apoptotic inducer. Biochemical and Biophysical Research Communications 2000277 476-486. (doi:10.1006/bbrc. 2000.3688)

28 Khanna N, Sen S, Sharma H \& Singh N. S29 ribosomal protein induces apoptosis in H520 cells and sensitizes them to chemotherapy. Biochemical and Biophysical Research Communications 2003304 26-35. (doi:10.1016/S0006-291X(03) 00532-1)

29 Vermeulen K, Berneman ZN \& Van Bockstaele DR. Cell cycle and apoptosis. Cell Proliferation 200336 165-175. (doi:10.1046/ j.1365-2184.2003.00267.x)

30 Yacoub A, Augeri L, Kelley MR, Doetsch PW \& Deutsch WA. A Drosophila ribosomal protein contains 8-oxoguanine and abasic site DNA repair activities. EMBO Journal 199615 2306-2312.

31 Kim J, Chubatsu LS, Admon A, Stahl J, Fellous R \& Linn S. Implication of mammalian ribosomal protein $\mathrm{S} 3$ in the processing of DNA damage. Journal of Biological Chemistry 1995270 13620-13629. (doi:10.1074/jbc.270.23.13620)

32 Jang CY, Lee JY \& Kim J. RpS3, a DNA repair endonuclease and ribosomal protein, is involved in apoptosis. FEBS Letters $2004 \mathbf{5 6 0}$ 81-85. (doi:10.1016/S0014-5793(04)00074-2)

33 Bettuzzi S, Brausi M, Rizzi F, Castagnetti G, Peracchia G \& Corti A. Chemoprevention of human prostate cancer by oral administration of green tea catechins in volunteers with highgrade prostate intraepithelial neoplasia: a preliminary report from a one-year proof-of-principle study. Cancer Research $2006 \mathbf{6 6}$ 1234-1240. (doi:10.1158/0008-5472.CAN-05-1145)

34 Tachibana H, Koga K, Fujimura Y \& Yamada K. A receptor for green tea polyphenol EGCG. Nature Structural \& Molecular Biology 200411 380-381. (doi:10.1038/nsmb743)

35 Umeda D, Yano S, Yamada K \& Tachibana H. Green tea polyphenol epigallocatechin-3-gallate signaling pathway through $67-\mathrm{kDa}$ laminin receptor. Journal of Biological Chemistry $2008 \mathbf{2 8 3}$ 3050-3058. (doi:10.1074/jbc.M707892200)

36 Cohen O, Inbal B, Kissil JL, Raveh T, Berissi H, Spivak-Kroizaman T, Feinstein E \& Kimchi A. DAP-kinase participates in TNF- $\alpha$ - and FAS-induced apoptosis and its function requires the death domain. Journal of Cell Biology 1999146 141-148. (doi:10.1083/jcb.146. 1.141)

37 Raveh T \& Kimchi A. DAP Kinase - a proapoptotic gene that functions as a tumor suppressor. Experimental Cell Research 2001 264 185-192. (doi:10.1006/excr.2000.5134)

38 Shammas MA, Neri P, Koley H, Batchu RB, Bertheau RC, Munshi V, Prabhala R, Fulciniti M, Tai YT, Treon SP, et al. Specific killing of multiple myeloma cells by (-)-epigallocatechin-3-gallate extracted from green tea: biologic activity and therapeutic implications. Blood 2006108 2804-2810. (doi:10.1182/blood2006-05-022814)

39 Negrutskii BS \& El'skaya AV. Eukaryotic translation elongation factor 1 alpha: structure, expression, functions, and possible role in aminoacyl-tRNA channeling. Progress in Nucleic Acid Research and Molecular Biology $1998 \mathbf{6 0} 47-78$.

40 Haupt YMR, Kazaz A \& Oren M. Mdm2 promotes the rapid degradation of p53. Nature 1997387 296-299. (doi:10.1038/ 387296a0) 
41 Dai MS, Zeng SX, Jin Y, Sun XX, David L \& Lu H. Ribosomal protein L23 activates p53 by inhibiting MDM2 function in response to ribosomal perturbation but not to translation inhibition. Molecular and Cellular Biology 200424 7654-7668. (doi:10.1128/MCB.24. 17.7654-7668.2004)

42 Chen D, Zhang Z, Li M, Wang W, Li Y, Rayburn ER, Hill DL, Wang $\mathrm{H}$ \& Zhang R. Ribosomal protein S7 as a novel modulator of p53-MDM2 interaction: binding to MDM2, stabilization of p53 protein, and activation of p53 function. Oncogene $2007 \mathbf{2 6}$ 5029-5037. (doi:10.1038/sj.onc.1210327)

43 Horn HF \& Vousden KH. Cooperation between the ribosomal proteins L5 and L11 in the p53 pathway. Oncogene 200827 5774-5784. (doi:10.1038/onc.2008.189)
44 Yadavilli S, Mayo LD, Higgins M, Lain S, Hegde V \& Deutsch WA. Ribosomal protein S3: a multi-functional protein that interacts with both p53 and MDM2 through its $\mathrm{KH}$ domain. DNA Repair 20098 1215-1224. (doi:10.1016/j.dnarep.2009. 07.003)

45 Deisenroth CZY. Ribosome biogenesis surveillance: probing the ribosomal protein-Mdm2-p53 pathway. Oncogene 201029 4253-4260. (doi:10.1038/onc.2010.189)

Received 3 May 2012

Accepted 19 September 2012 